\title{
Úlcera de córnea em equino - relato de caso
}

Antônio Catunda Pinho Neto ${ }^{[]^{*}}$, Elen Maiza Souza Sena $a^{[b]}$, José Ivan Caetano Fernandes Filho $0^{[c]}$, Camila Goersch Barroso ${ }^{[d]}$, Heloísa de Paula Pedrosa ${ }^{[]]}$, Rodrigo martins Ribeiro ${ }^{[a]}$, Ocelio Pereira da Silva ${ }^{[e]}$

\author{
[a] Universidade Federal de Minas Gerais (UFMG), Belo Horizonte, MG, Brasil \\ [b] Universidade Presidente Antônio Carlos (UNIPAC), Conselheiro Lafayete, MG, Brasil \\ [c] Faculdade Cisne, Quixadá, CE, Brasil \\ [d] Universidade Estadual do Ceará (UECE), Fortaleza, CE, Brasil \\ ${ }^{[\mathrm{e}]}$ Vetnil, Fortaleza, CE, Brasil
}

*Autor correspondente

e-mail: antoniocatunda@hotmail.com

\section{Resumo}

Apesar de ser uma das enfermidades mais comuns da oftalmologia equina, a úlcera de córnea é um dos problemas mais desafiadores na clínica médica de equinos, pois o sucesso no tratamento é menos frequente quando comparado a outras espécies. Os olhos proeminentes dos equinos favorecem os acidentes traumáticos, sendo esta a causa principal para o desenvolvimento da ulceração corneana; portanto as infecções secundárias devem sempre ser consideradas. Os sinais clínicos comumente apresentados são epífora, blefaroespasmo, fotofobia, edema de córnea, hiperemia conjuntival e, possivelmente, miose. 0 diagnóstico da úlcera corneana é feito por meio dos sinais clínicos e da retenção do corante de fluoresceína, que auxilia na identificação da extensão da úlcera corando o epitélio lesado na tonalidade verde brilhante. Foi atendida uma égua, com 2 meses de gestação, pelagem preta, 5 anos de idade, da raça Mangalarga Machador. Foi relatado que o animal apresentava uma mancha arredondada branca no olho esquerdo, com um histórico de que a lesão ocorreu durante o transporte do animal de Recife/PE para Cascavel/CE. Ao exame clínico de inspeção, observou-se presença de ectoparasitas, escore corporal 2, lesões no chanfro, região do masseter. Ao exame oftálmico, ficou constatado que a paciente apresentava blefaroespasmo, blefarite, alta sensibilidade à luz e edema corneano focal, no globo ocular esquerdo. Em virtude da escassez de recursos apropriados para um diagnóstico preciso, este animal foi tratado como um caso de úlcera de córnea. Foi instituída terapia por via tópica com $1 \mathrm{ml}$ de soro sanguíneo do próprio animal após ser heparinizado, três vezes ao dia, $1 \mathrm{ml}$ de sulfato de condroitina A associado ao sulfato de glucosamina (Condroton ${ }^{\circledR}$ ), uma vez 
ao dia, e pomada oftálmica à base de gentamicina, hidrocortisona, vitamina A e D (Keravit ${ }^{\circledR}$ ), três vezes ao dia, aplicados na pálpebra inferior e massageados para que abrangessem toda a superfície do olho. Após 48 horas de tratamento, o animal apresentou melhora significativa da lesão ocular e, em sete dias, a remissão completa de todos os sintomas e sinais apresentados. No relato apresentado, o diagnóstico foi baseado nos sinais clínicos, que condizem com a lesão. A úlcera de córnea pode ser caracterizada de acordo com a área, profundidade e presença ou ausência de infiltração celular, sendo classificadas como não complicadas ou complicadas. 0 tratamento da úlcera corneana sem complicações abrange o controle da dor e da inflamação, eliminação ou prevenção de infecções e profilaxia de complicações secundárias. A cicatrização ocorre por migração e mitose das células epiteliais adjacentes e pode estar completa de 2 a 6 dias, dependendo do tamanho da lesão. 0 uso do Condroton ${ }^{\circledR}$ teve o intuito de fornecer substrato para a regeneração corneal. A pomada Keravit ${ }^{\circledR}$ possui em sua formulação: gentamicina, antibiótico de amplo espectro que possui excelente penetração no tecido córneo; vitaminas A e D, que favorecem o crescimento do ceratócitos, auxiliando no processo de cicatrização e remodelação da lesão; corticoide, que diminui a vascularização e, portanto, o transporte de células inflamatórias e a atividade fibroblástica, inibindo a formação de cicatrizes hipertóficas, queloide e edema. Apesar de potencializar a colagenase e diminuir o mecanismo de resistência contra infecções, o critério adotado para o seu uso foi a total cicatrização da córnea. A aplicação tópica de soro autógeno heparinizado foi utilizada no protocolo da terapia por auxiliar o processo de cicatrização do epitélio corneano. As enzimas com ação antiproteolíticas presentes no soro inibem a ativação e produção de proteases e colagenases que degradam o colágeno, principal proteína da matriz celular ocular. 0 protocolo adotado foi eficaz para o tratamento de úlcera de córnea, demonstrando uma resolução completa da lesão sete dias após o início da terapia instituída.

Palavras-chave: Ulceração corneana. Cavalo. Olho. 